\title{
HUBUNGAN ANTARA KECERDASAN EMOSIONAL, PERILAKU DELINKUENSI, DAN PRESTASI BELAJAR PADA REMAJA MADYA DI SLTA JAKARTA (Studi pada Siswa/i di SMA X, SMK Y, dan SMK Z)
}

\author{
Azalia Febiyanti $^{1}$ dan Erik Wijaya ${ }^{2}$ \\ ${ }^{1}$ Fakultas Psikologi, Universitas TarumanagaraJakarta \\ Email: azalia.febiyanti@gmail.com \\ ${ }^{2}$ Fakultas Psikologi, Universitas TarumanagaraJakarta \\ Email: erikfght@yahoo.com
}

\begin{abstract}
ABSTRAK
Tujuan dari penelitian ini adalah untuk menguji hubungan antara kecerdasan emosional, kenakalan remaja, dan prestasi remaja menengah di Jakarta. Kecerdasan emosional adalah kemampuan dan keterampilan yang berkaitan dengan pengembangan hubungan sosial dengan lingkungan mengacu pada kemampuan mengenali perasaan dan perasaan mereka sendiri, kemampuan untuk memotivasi diri sendiri, dan kemampuan mengelola emosi dengan baik, dan dalam hubungan dengan orang lain. Kenakalan remaja adalah kenakalan umum pada remaja dan melanggar norma. Prestasi adalah hasil dan dilakukan oleh seseorang. Penelitian ini memiliki 351 subjek di SMA di Jakarta. Hasilnya menunjukkan bahwa kecerdasan emosional memiliki korelasi negatif dan signifikan dengan kenakalan remaja dengan $r=-0,247$ dan $p=0,000$. Kenakalan dan prestasi remaja memiliki korelasi negatif dan signifikan dengan $r=-0,210$ dan $p=0,000$. Kecerdasan emosional tidak memiliki korelasi dengan prestasi dengan $r=0,079$ dan $p=0$,319. Kesimpulan dari penelitian ini adalah kecerdasan emosional yang lebih tinggi adalah kenakalan remaja yang lebih rendah dan kenakalan remaja yang lebih rendah adalah prestasi yang lebih tinggi. Namun kecerdasan emosional yang tinggi belum tentu berprestasi tinggi.
\end{abstract}

Kata kunci: Kecerdasan Emosional, Kenakalan Remaja, Prestasi, dan Remaja Madya

\section{PENDAHULUAN}

\section{Latar Belakang}

Masa remaja (12-21 tahun) merupakan masa peralihan antara masa kehidupan anak-anak dan masa kehidupan orang dewasa. Masa remaja sering dikenal dengan masa pencarian jati diri (ego identity). Masa remaja ditandai dengan sejumlah karakteristik penting, seperti mencapai hubungan yang matang dengan teman sebaya; dapat menerima dan belajar peran sosial sebagai pria atau wanita dewasa yang dijunjung tinggi oleh masyarakat; menerima keadaan fisik dan mampu menggunakannya secara efektif; mencapai kemandirian emosional dari orangtua dan orang dewasa lainnya; memilih dan mempersiapkan karier di masa depan sesuai dengan minat dan kemampuannya; mengembangkan sikap positif terhadap pernikahan, hidup berkeluarga dan memiliki anak; mengembangkan keterampilan intelektual dan konsep-konsep yang diperlukan sebagai warga negara; mencapai tingkah laku yang bertanggung jawab secara sosial; memperoleh seperangkat nilai dan sistem etika sebagai pedoman dalam bertingkah laku; dan mengembangkan wawasan keagamaan dan meningkatkan religiusitas (Desmita, 2010).

Secara umum, Konopka (dalam Agustiani, 2006) membagi masa remaja menjadi tiga bagian. Pertama, masa remaja awal (12-15 tahun). Pada masa ini individu mulai meninggalkan peran sebagai anak-anak dan berusaha mengembangkan diri sebagai individu yang unik dan tidak tergantung pada orangtua. Fokus dari tahap ini adalah penerimaan terhadap bentuk dan kondisi fisik serta adanya konformitas yang kuat dengan teman sebaya. Kedua, masa remaja pertengahan atau madya (15-18 tahun). Masa ini ditandai dengan berkembangnya kemampuan berpikir yang baru. Pada masa ini remaja mulai mengembangkan kematangan tingkah laku, belajar mengendalikan impulsivitas, dan membuat keputusan-keputusan awal yang berkaitan dengan 
tujuan vokasional yang ingin dicapai. Selain itu penerimaan dari lawan jenis menjadi penting bagi individu. Monks, Knoers, dan Haditono (1996) menambahkan bahwa remaja madya atau pertengahan tergolong sebagai pelajar sekolah menengah atau perguruan tinggi awal. Ketiga, masa remaja akhir (19-22 tahun). Masa ini ditandai oleh persisapan akhir untuk memasuki peranperan orang dewasa. Selama periode ini remaja berusaha memantapkan tujuan vokasional dan mengembangkan sense ofpersonal identity.

Berdasarkan hal tersebut, salah satu tugas penting dari remaja adalah untuk meraih prestasi yang baik di sekolah. Dalam Kamus Psikologi, prestasi belajar didefinisikan sebagai satu tingkat khusus dari kesuksesan karena mempelajari tugas-tugas, atau tingkat tertentu dari kecakapan atau keahlian dalam tugas-tugas sekolah atau akademis (Chaplin, 2008). Menurut Sumadi Suryabrata (2005) prestasi belajar adalah kemampuan siswa yang berupa penguasaan pengetahuan, sikap, dan keterampilan yang dicapai dalam belajar setelah siswa melakukan kegiatan belajar. Prestasi belajar siswa dapat diketahui dengan guru memberi nilai pada siswa. Hasil belajar siswa dapat diukur dengan cara memberikan tugas, menanyakan beberapa hal yang berkaitan dengan pelajaran tertentu, memberikan tes pada siswa sesudah mengikuti pelajaran tertentu, dan memberikan ulangan.

Di Indonesia ditemukan berbagai masalah dalam dunia pendidikan yaitu menurunnya akhlak dan moral peserta didik, kurang meratanya kesempatan belajar, rendahnya efisiensi internal sistem pendidikan, status kelembagaan pendidikan di Indonesia belum memiliki sistem, manajemen pendidikan yang tidak selaras dalam pemabangunan nasional, dan belum profesionalnya sumber daya manusia yang bergerak dalam dunia pendidikan (Nurhadi, 2004). Dengan demikian, dampak yang dapat diamati adalah hasil pendidikan kurang memuaskan dan memprihatinkan sehingga peserta didik tidak memiliki prestasi belajar yang baik (Stevanus \& Mulat, 2005).

Menurut Goleman (2002), kecerdasan intelektual (IQ) hanya menyumbang 20\% bagi kesuksesan, sedangkan $80 \%$ adalah sumbangan faktor kekuatan-kekuatan lain, diantaranya adalah kecerdasan emosional atau Emotional Quotient (EQ) yakni kemampuan memotivasi diri sendiri, mengatasi frustasi, mengontrol desakan hati, mengatur suasana hati ( $\mathrm{mood}$ ), berempati serta kemampuan bekerja sama.

Efek dari kecerdasan emosi yang kurang baik juga berakibat terjadinya penurunan akhlak yang menyebabkan prestasi belajar menjadi tidak baik pada peserta didik yang masih remaja. Perilaku menyimpang yang dilakukan oleh remaja yang telah mengarah pada bentuk kriminalitas. Berbagai bentuk perilaku menyimpang yang dilakukan remaja ini dikenal dengan istilah kenakalan remaja atau perilaku delinkuensi (Juvenile Delinquency). Ediati (2004) berpendapat mengenai perilaku delinkuensi yang menyatakan sebagai perilaku yang melanggar norma sosial, hukum, dan agama yang dilakukan oleh orang yang belum dewasa (dibawah usia 18 tahun). Sudarsono (1995) mengatakan tindakan yang melanggar norma seperti pemerasan, penganiayaan, pencurian, penyalahgunaan obat, perusakan bis kota dengan melempari kacanya. Mulyono (1995) juga memberikan pendapatnya bahwa perilaku delinkuensi merupakan kenakalan remaja yang terbatas pada usia sekitar 13-15 tahun sampai usia 21 tahun. Sarwono (2005) memaparkan empat bentuk perilaku delinkuensi yaitu, kenakalan yang menimbulkan korban fisik, kenakalan yang menimbulkan korban materi, kenakalan melawan status, kenakalan yang tidak menimbulkan korban pihak lain.

Berdasarkan hal tersebut maka penting untuk para remaja ini difasilitasi untuk memperbaiki kecerdasan emosionalnya sehingga perilaku delinkuensi menurun dan prestasi belajar menjadi 
meningkat. Peneliti merasa penting untuk melihat hubungan dari ketiga variabel tersebut karena dalam rangka pembahasan lebih mendalam mengenai penanganan perilaku kenakalan remaja sehingga prestasi belajar dapat meningkat.

\section{Rumusan Masalah}

Apakah ada hubungan antara kecerdasan emosional, perilaku delinkuensi, dan prestasi belajar pada remaja madya?

\section{Tujuan Penelitian}

Untuk mengetahui hubungan antara kecerdasan emosional, perilaku delinkuensi, dan prestasi belajar pada remaja madya di SLTA Jakarta.

\section{METODE PENELITIAN}

Penelitian ini merupakan jenis penelitian kuantitatif dengan bentuk non eksperimental. Penelitian ini merupakan penelitian korelasional Spearman yang menggambarkan hubungan antara kecerdasan emosional dengan prestasi belajar pada remaja madya yang dianggap berperilaku delinkuensi yang sedang duduk di bangku SLTA, baik SMA maupun SMK. Penelitian ini terdiri dari tiga variabel. Ketiga variabel tersebut adalah variabel kecerdasan emosional, variabel prestasi, dan variabel perilaku delinkuensi. Penelitian ini ingin menggambarkan tingkat kecerdasan emosional seseorang dapat mempengaruhi prestasi belajar pada remaja madya yang dianggap memiliki perilaku delinkuen. Untuk itu penelitian ini didesain dengan mengambil sampel komunitas remaja madya yang dianggap berperilaku delinkuen dan berada di bangku SLTA dengan membagikan kuesioner.

Subyek penelitian yang diambil untuk penelitian ini adalah remaja madya baik pria maupun wanita berusia 15-18 tahun, berdomisili di Jakarta. Penelitian ini tidak membatasi pada agama tertentu. Sampel yang digunakan adalah sekolah lanjutan tingkat atas (SLTA) baik SMA maupun SMK, yang memiliki murid dengan perilaku delinkuen atau sekolah yang memiliki track record sebagai "sekolah nakal". Peneliti memperoleh subyek sebanyak 436 partisipan dari tiga sekolah lanjutan tingkat atas di Jakarta, namun hanya 351 partisipan yang mampu menjawab keseluruhan kuesioner dengan baik sehingga pada akhirnya peneliti hanya mampu mendapatkan subyek sebanyak 351 partisipan, yang terdiri dari 259 partisipan laki-laki dan 92 partisipan perempuan. Penelitian ini menggunakan teknik pengambilan sampel nonprobabilitas sampling. Jenis penarikan sampel yang digunakan adalah jenis penarikan sampel dengan mengambil jumlah keseluruhan dari populasi (sampling jenuh). Teknik pengambilan sampel ini dipilih berdasarkan beberapa pertimbangan mengenai efisiensi, efektivitas, serta memudahkan penelitian.

\section{HASIL DAN PEMBAHASAN}

Gambaran subyek penelitian ini dapat dilihat berdasarkan jenis kelamin, nama sekolah, usia, agama, dan nilai rapor dari subyek. Berdasarkan data yang diperoleh dari jenis kelamin, subyek berjenis kelamin laki-laki berjumlah 259 orang dengan persentase sebesar $73,8 \%$ dan subyek berjenis kelamin perempuan berjumlah 92 orang dengan persentase sebesar 26,2\%. Berdasarkan data yang diperoleh, subyek penelitian yang bersekolah di SMA X berjumlah 85 orang dengan persentase sebesar 24,2\%, subyek penelitian yang bersekolah di SMK Y berjumlah 136 orang dengan persentase sebesar 38,7\%, dan subyek penelitian bersekolah di SMK Z berjumlah 130 orang dengan persentase sebesar $37,0 \%$. Berdasarkan data yang diperoleh, subyek penelitian yang berusia 16 tahun berjumlah 63 orang dengan persentase sebesar 17,9\%, subyek penelitian 
yang berusia 17 tahun berjumlah 248 orang dengan persentase 70,7\%, dan subyek penelitian yang berusia 18 tahun berjumlah 40 orang dengan persentase sebesar 11,4\%.

Selanjutnya merupakan data subyek berdasarkan nilai rapor. Nilai rapor yang frekuensi tertinggi adalah 80 berjumlah 69 orang dengan persentase 19,7\%. Niai rapor dengan frekuensi terendah $69,71,91$, dan 94 berjumlah 1 orang dengan persentase $0,3 \%$.

Uji normalitas data menggunakan one sample $K-S$ untuk melihat apakah data terdistribusi normal atau tidak. Berdasarkan hasil uji, terlihat bahwa variabel kecerdasan emosional terdistribusi dengan normal. Hal tersebut terlihat dari nilai $p$ (asymptotic significance) pada variabel tersebut memiliki nilai yang lebih besar dari 0,05 pada pengujian Kolmogorov-Smirnov. Sedangkan perilaku delinkuensi, dan prestasi belajar tidak terdistribusi normal sehingga pada pengujian hipotesis digunakan teknik analisis nonparametrik. Hal ini terlihat dari niai $p$ pada kedua variabel tersebut lebih kecil dari 0,05.

Pada bagian ini akan dibahas mengenai ada atau tidaknya hubungan antara kecerdasan emosional, perilaku delinkuensi, dan prestasi belajar. Untuk mencari ada atau tidaknya hubungan tersebut peneliti menggunakan metode uji korelasi Spearman karena ada data distribusi yang tidak normal. Semua analisis data yang dilakukan dengan bantuan program SPSS versi 20.00.

Pengujian korelasi antara kecerdasan emosional, perilaku delinkuensi, dan prestasi belajar dilakukan dengan menggunakan perhitungan korelasi Spearman karena terdapat data yang tidak normal. Hasil perhitungan korelasi antara kecerdasan emosional dan perilaku delinkuensi menunjukkan bahwa $r=-0,247$ dan $p=0,000$ sehingga dapat disimpulkan bahwa kecerdasan emosional memiliki hubungan yang negatif dan signifikan dengan perilaku delinkuensi. Hal ini berarti semakin tinggi kecerdasan emosional remaja madya maka semakin rendah kecenderungan remaja madya untuk melakukan perilaku delinkuensi. Perilaku delinkuensi juga memiliki hubungan yang negatif dan signifikan dengan prestasi belajar dengan nilai $r=-0,210$ dan nilai $p$ $=0,000$. Hal ini berarti semakin rendah kecenderungan remaja madya untuk melakukan perilaku delinkuensi maka semakin tinggi prestasi belajar yang diraih oleh remaja madya. Namun, tidak terdapat hubungan yang signifikan antara kecerdasan emosional dengan prestasi belajar. Hal ini ditandai dengan nilai $r=0,79$ dan nilai $p=0,139$. Hal ini berarti kecerdasan emosional remaja madya tidak memperngaruhi prestasi belajar remaja madya yang mungkin disebabkan oleh banyak faktor.

Pengujian korelasi menggunakan perhitungan korelasi Spearman. Hasil analisa data menunjukkan bahwa semua dimensi perilaku delinkuensi memiliki hubungan yang signifikan dengan prestasi belajar. Dimensi kenakalan yang menimbulkan korban fisik terdapat hubungan yang signiffikan dengan prestasi belajar. Hal ini terlihat dari nilai $r=-0,140$ dan nilai $p=0,009$. Dimensi kenakalan yang menimbulkan korban materi memiliki hubungan yang signifikan dengan prestasi belajar. Hal ini dapat dilihat dari nilai $r=-0,161$ dan nilai $p=0,002$. Dimensi kenakalan melawan status juga memiliki hubungan yang signifikan dengan prestasi belajar dengan nilai $r=-0,120$ dan nilai $p=0,025$. Dan dimensi yang terakhir yaitu kenakalan yang tidak menimbulkan korban pihak lain juga memiliki hubungan yang signifikan dengan prestasi belajar dengan nilai $r=-0.306$ dan $p=0,000$. 


\section{KESIMPULAN DAN SARAN}

Berdasarkan analisis data yang telah dilakukan mengenai hubungan kecerdasan emosional, perilaku delinkuensi, dan prestasi belajar pada remaja madya, maka dapat disimpulkan bahwa terdapat hubungan yang negatif dan signifikan antara kecerdasan emosional dengan perilaku delinkuensi dan perilaku delinkuensi dengan prestasi belajar. Namun tidak terdapat hubungan antara kecerdasan emosional dengan prestasi belajar. Hasil penelitian menunjukkan bahwa kecerdasan emosional memiliki hubungan dengan perilaku delinkuensi dengan nilai $r=-0,247$ dan nilai $p=0,000$. Semakin tinggi kecerdasan emosional yang dimiliki seseorang maka akan semakin rendah perilaku delinkuensi yang dimilikinya. Perilaku delinkuensi memiliki hubungan dengan prestasi belajar dengan nilai $r=-0,210$ dan nilai $p=0,000$. Semakin rendah perilaku delinkuensi yang dimiliki seseorang maka semakin tinggi prestasi belajar yang dicapai. Sedangkan, kecerdasan emosional tidak memiliki hubungan dengan prestasi belajar dengan nilai $\begin{array}{llllll}r & 0,079 & \text { dan } & \text { nilai } & p & 0,139\end{array}$

\section{Saran}

Saran untuk penelitian selanjutnya yang perlu diperhatikan adalah penggunaan metode penelitian. Metode penelitian kualitatif untuk meneliti perilaku delinkuensi dapat menggali lebih dalam perilaku delinkuensi yang sesungguhnya terjadi. Untuk itu lebih diperhatikan mengenai metode penelitian yang digunakan. Kemudian perlu diperhatikan pula penyebab terjadinya perilaku delinkuensi pada remaja. Kecerdasan emosional memang memiliki pengaruh terhadap perilaku delinkuensi. Namun dari hasil penelitian yang dilakukan, sekolah yang menjadi subyek penilitian ternyata memiliki perilaku delinkuensi yang rendah meskipun sekolah tersebut seringkali terlibat dalam tawuran. Oleh karena itu penelitian selanjutnya perlu meneliti faktorfaktor lain yang menjadi penyebab tawuran antar sekolah seperti adanya kemungkinan alumni sekolah tersebut masih berperan besar dalam terjadinya tawuran antar sekolah karena kebencian dengan sekolah tertentu yang ingin diwariskan oleh para alumni kepada para juniornya. Kemungkinan berikutnya adalah konformitas yang menjadi alasan terjadinya tawuran antar sekolah karena adanya rasa solidaritas yang tinggi di kalangan remaja.

Saran berikutnya terkait dengan kebenaran data mengenai nilai rapor atau hasil belajar siswa yang dilakukan oleh peneliti tidak memiliki bukti yang kuat bahwa nilai rapor yang ditulis oleh subyek adalah benar. Sehingga perlu meminta bantuan pihak sekolah memastikan bahwa nilai rapor yang ditulis para siswa adalah benar adanya atau meminta siswa untuk menyertakan fotocopy rapor.

\section{Ucapan Terima Kasih}

Peneliti juga tidak lupa mengucapkan terima kasih kepada Kepala Sekolah dan Wakil Kepala Sekolah, serta guru BK SMA X, SMK Y, dan SMK Z yang mengizinkan peneliti mengambil data penelitian dengan menyebarkan kuesioner kepada seluruh siswa dan siswi di sekolah tersebut. Terima kasih juga kepada seluruh siswa siswi SMA X, SMK Y, dan SMK Z yang bersedia meluangkan waktu mengisi kuesioner dari peneliti.

\section{REFERENSI}

Agustiani, H. (2006). Psikologi perkembangan. Bandung: Refika Aditama. Ahmadi, A. \& Supriyono, W. (1991). Psikologi Belajar. Jakarta: Rineka Cipta. Ali, L. (1991). Kamus Besar Bahasa Indonesia. Jakarta: Balai Pustaka. 
Aziz, R. \& Mangestuti, R. (2006).Pengaruh kecerdasan intelektual (IQ), emosional (EI), dan spiritual (SI) terhadap agresivitas pada mahasiswa UIN Malang. EI-Qudwah,1(1),113118.

Bloom, B.S. (2007). Taxonomy of educational objectives. New York, NY: David Mc. Kay.

Buist, K. L. (2010). Sibling relationship quality and adolescent delinquency: A latent growth curve approach. Journal of Family Psychology, 24(4), 400-410.

Caesaria, L. (2010). Hubungan antara manajemen waktu dan prestasi belajar pada anggota unit kegiatan mahasiswa di Universitas Indonesia. Skripsi tidak diterbitkan, Fakultas Psikologi, Universitas Indonesia.

Chaplin, J. P. (2008). Kamus lengkap psikologi. Jakarta: Raja Grafindo Persada.

Corsini, R. (2002). The dictionary of psychology. New York, NY: Brunner/Routledge.

Dalyono, M. (2005). Psikologi pendidikan. Jakarta:

Rineka Cipta.

Daud, M. (2010). Pengaruh kecerdasan emosional terhadap prestasi belajar mahasiswa jurusan pendidikan teknik bangunan fakultas teknik Universitas Negeri Manado. Jurnal Anima 1(1),86-97.

Desmita. (2010). Psikologi Perkembangan peserta Didik. Bandung: Remaja Rosdakarya.

Ediati, A. (2004). Kecenderungan remaja berperilaku delinkuen ditinjau dari dorongan mencari sensasi dan persepsi terhadap tersedianya dukungan dari teman sebaya. Jurnal Psikologi. UNDIP, 1(2), 119-130.

Efendi, A. (2005). Revolusi kecerdasan abad 21, kritik MI, EI, SQ, AQ, \& successful intelligences atas IQ. Bandung: Alfabeta.

Gardner, J. E. (1996). Memahami gejolak masa remaja (edisi ke-5). Jakarta: Mitra Utama.

Goleman, D. (1997). Emotional intelligence. (T. Hermaya, Terj.). Jakarta: Gramedia Pustaka Utama.

Goleman, D. (2002). Emotional intelligence . (T. Hermaya, Terj.). Jakarta: Gramedia Pustaka Utama.

Goleman, D. (2004). Working with emotional intelligence. New York, NY: Bantam Books.

Goleman, D. (2006). Emotional intelligence, kecerdasan emosional: mengapa EQ lebih penting daripada IQ . (T. Hermaya, Terj.). Jakarta. Gramedia Pustaka Utama.

Gunarsa, Y. \& Gunarsa, S. (2012). Psikologi remaja. Jakarta: BPK Gunung Mulia.

Haniman, F. (2000). Citra diri dan kenakalan remaja pada siswa smu/k (slta) peringkat tinggi dan peringkat rendah di Surabaya. Jurnal Anima, 15(3), 238-245.

Iman, J., Haniman, F., \& Moeljohardjo, H. (2000). Perbedaan konsep dan perilaku kenakalan remaja antara pelajar dari smu/k (slta) yang mendapat peringkat tinggi dengan $\mathrm{smu} / \mathrm{k}$ yang mendapat peringkat rendah di kotamadya Surabaya. Jurnal Anima, 15(3), 225-268.

Jurnal Sri Gunting. (2012). Diunduh 29 Maret 2014, dari http://jurnalsrigunting.com/2012/10/09/fenomena-tawuran-pelajar-berdasarkanperspektif-differential-association-theory/

Kartono, K. (1998). Psikologi sosial 2: kenakalan remaja dan penanganannya. Jakarta: Raja Grafindo Persada.

Martin, C. A., \& Colbert, K. K. (2007). Parenting: A life span perspective. New York, NY: McGraw-Hill.Merdeka. (2014). Diunduh 8 November 2014, dari http://m.merdeka.com/peristiwa/penyiraman-air-keras-siswa-smk-boedoet-berawalsaling-ejek.html/

Meyer, J.D \& Salovey, P. (1997). What is emotional intellegence? New York, NY: Basic Book.

Monks, F. J, Knoers, A. M. P., \& Haditono, S. R. (1996). Psikologi perkembangan: pengantar dalam berbagai bidangnya. Yogyakarta: Gadjah Mada University Press. 
Mulyono, Y. (1995). Pendekatan analisis kenakalan remaja dan penanggulangannya. Yogyakarta: Kanisius.

Nurhadi. (2004). Kurikulum 2004: Pertanyaan dan jawaban. Jakarta: Grasindo.

Purnaningtyas, A. (2010). Pengaruh kecerdasan emosi terhadap prestasi belajar siswa mata pelajaran seni budaya SMP. Journal of Arts Research and Education, 10(1), 30-32.

Papalia, D. E., Olds, S. W., \& Feldman, R. D. (2001). Human development ( $\left.8^{\text {th }} \mathrm{ed}\right)$. New York, NY: Mc Graw-Hill.

Ratnawati, M. (1996). Hubungan antara persepsi anak terhadap suasana keluarga,citra diri, dan motif berprestasi dengan prestasi belajar pada siswa kelas V SD Ta'Miriyah Surabaya. Jurnal Anima, 11(3), 56-60.

Santrock, J.W. (2001). Child development (Ed. $\left.9^{\text {th }}\right)$. New York, NY: McGraw-Hill.

Sarwono, S. W. (2000) Berkenalan dengan tokoh dan aliran psikologi. Jakarta: Bulan Bintang.

Sarwono, S. W. (2005). Psikologi remaja. Jakarta: Raja Grafindo Persada.

Setianingsih, E. Uyu, Z. \& Yuwono, S. (2006). Hubungan antara penyesuaian sosial dan kemampuan menyelesaikan masalah dengan kecenderungan perilaku delinkuen pada remaja. Jurnal Psikologi Universitas Diponegoro, 3(1), 15-17.

Siddiqah, L. (2010). Pencegahan dan penanganan perilaku agresif remaja melalui pengelolaan amarah. Jurnal Psikologi, 37(1), 101-104.

Simadjuntak, B. \& Pasaribu. (1979). Psikologi Perkembangan Dasar Psikokriminal. Bandung: Tarsitu.

Stevanus, I., \& Mulat, S. P. E. (2006). Sikap guru sd majelis pendidikan katolik keuskupan agung Jakarta terhadap pelaksanaan kurikulum berbasis kompetensi. Psiko-Edukasi. Jurnal Pendidikan, Psikologi, dan Konseling, 3(2), 128-145.

Sudarsono. (1995). Kenakalan remaja: prevensi, rehabilitasi dan resosialisasi. (edisi ke-2). Jakarta: Rineka Cipta.

Sumadi, S. (2005). Psikologi pendidikan. Jakarta: PT. Raja Grafindo Persada.

Susanty, S. (2007). Iklim lingkungan kelas mempengaruhi prestasi akademik? Provitae, 3(1), 5583.

Vivanews. (2012). Diunduh 13 Desember 2014, dari http://m.news.viva.co.id/news/read/353921tawuran-sma-6-dan-sma-70-makan-korban-polisi-kecolongan/

Vivanews. (2012). Diunduh 13 Desember 2014, dari http://m.news.viva.co.id/news/read/359758tawuran-di-pancoran--6-siswa-stm-penerbangan-jadi-tersangka/

Wasty Soemanto. (1984). Psikologi pendidikan. Jakarta: Bina Aksara.

Weisinger, H. (2006). Emotional intelligence at work: pemandu pikiran dan perilaku anda untuk meraih kesuksesan. Jakarta: Bhuana lmu Populer.

Winkel, WS. (1997). Psikologi pendidikan dan evaluasi belajar. Jakarta: Gramedia.

Yahaya, A. Yahaya, N. \& Juriah, J. (2007). Perkaitan antara hubungan kekeluargaan, pengaruh rekan sebaya dan kecerdasan emosional dengan tingkah laku delinkuensi pelajar sekolah bestari di daerah pontian. Jurnal Master, 134-145.

Wijaya, E. (2007). Hubungan antara pendidikan nilai agama dengan perilaku delinkuensi pada remaja madya di sekolah menengah atas (SMA). Skripsi, tidak diterbitkan. Universitas Tarumanagara Jakarta. 